42 . 電気機器等の異常による電源電圧の異常例

小林 堅 ${ }^{11}$ ，白井敦史 ${ }^{11}$ ，田村千秋 ${ }^{11}$ ，瓜生伸一 ${ }^{11}$ ，渡辺 敏 ${ }^{12}{ }^{2131}$ ，川村 正春 ${ }^{41}$

1) 北里大学東病院MEセンター部

3)北里大学病院M Eセンター部

1.はじめに

現在の医㞠は奄気に対する依存度が大きく、 適正な電源の供給が行われないと、医療機器 および病院機能は、その本来の機能を発揮し ない。このためには電気設備の安全性、信頼 性を維持し、安定した定格电圧の供給が必要 である。

しかしながら、院内各部門で使用している 各種電気機器の異常等で、電源電圧の異常が 起こる可能性があり、この時には院内全体の 䉓源供給に影整を与える危険性がある。

今回、当施設内の電気機器の軋䃇コード損 倁およびコンセントの誤即線が原因で、院内 全体の非常電源および一般電碩に対地間电圧 異常が発生した実例を経敄したので報告する。

\section{2. 状況および原因}

\section{2-1 事例 1}

電圧異常を確認したのは平成5年10月7日16 :00ご M E センター部にて医療機器（輸注ボ ンプN0.7）の接地漏れ電流測定中で、単一故 障時の值が $281 \mu \mathrm{A}$ (通常 $130 \mu \mathrm{A}$ 前後) と通常 より増大していたためSAFETY/ECG ANALYZER (DYNATECH NEVADA) で一般電源コンセントの電 圧を測定したところHOT-GND 171.0V、NEUTRA L-GND 97.3V、HOT-NEUTRAL 100.3V とGND間に 100V近い電圧がかっていることが分かった。

事態発生後直ちに施設係職員およびM E ンター部職員により院内の供給鼋䃇電圧の調 查を行った。

16:10 各病棟の一般電源、特別非常奄源の各 コンセントへの供給電圧は M E センタ一部内 と同様にGND間に異常電圧值を示していたが、 人工呼吸器等に使用している睛時特別非常電 源においては定格電圧值であった。

17:00 末端で使用している医療機器の絶縁不 良等の原因す考えられるため、院内で使用し ている医療機器で点検可能なものに対しては 電源コンセントより電源プラグ外し調查を行 った。

21:30 電気室の配電盤の調查により一般電灯 電源回路NO.2の異常箇所が分かった。（表一 1 参照)
2) 北里大学医療街生学部臨床工学

4) 北里大学東病院事務部総務課施設係

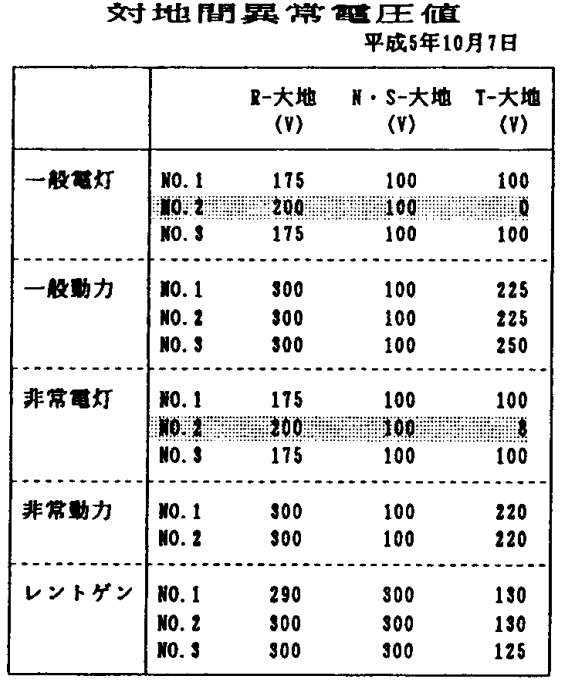

$$
\text { 表- } 1
$$

8日9:00ごろ3西病棟（370号室）の一室が停 電した。原因はベットランプ電源コードが破 損しショートしたためであった。（写真ー1）

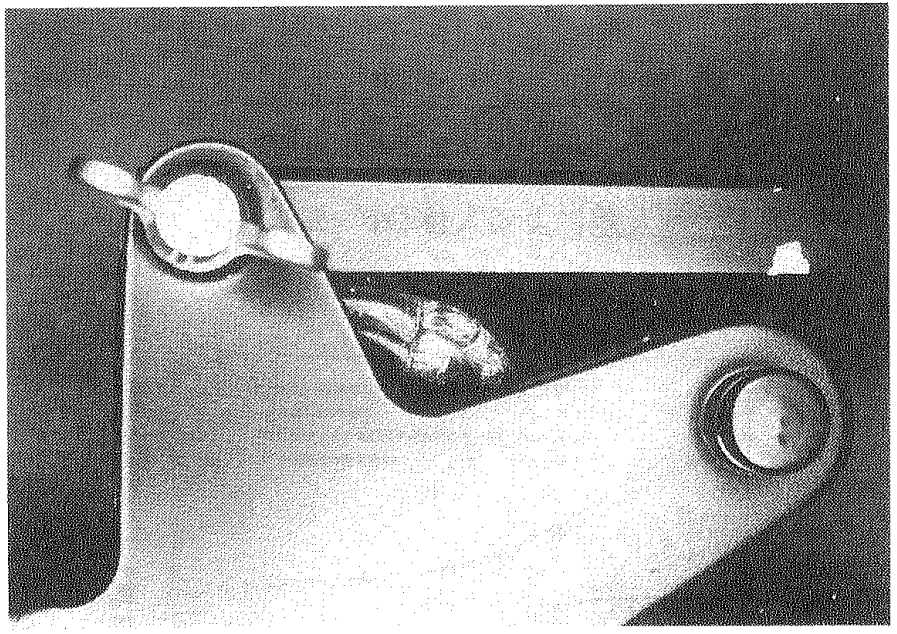

写真 -1

このベットランプの交換と同時刻ごろに電圧 が正常に復帰しているのが確認された。

尚、配電盤の異常箇所から手術室および病棟 で正常電圧に復㸟した時間 9:00以前まで使用 していた医療機器等に対し調查を行ったが特 に異常は確認されなっかた。 
このため、電圧が正常に復帰した時刻とほぼ 一致するため、このべットランプが原因であ ったものと推測される。

\section{2-2 事例 2}

10月12日午前8時50分前回同様当センタ一内 において再度異常電圧を確認、電気設備の点 検調查を行ったところ院内全体の一般および 非常電奵、動力電源に対地間電圧異常が確認 された。

しかし、今回の電圧異常は10月7日に発生し た電圧異常とは異なった数值を示した。

また、異常電圧の発生が不定期であり、なお 且つ短時間であることから、異常電圧発生源 の傾向を把握するため連続電圧記録計を使用 し一般電源コンセントで测定を行った。

测定を行った結果、約 1 時間毎に電圧の変動 が見られた。（図一1参照）

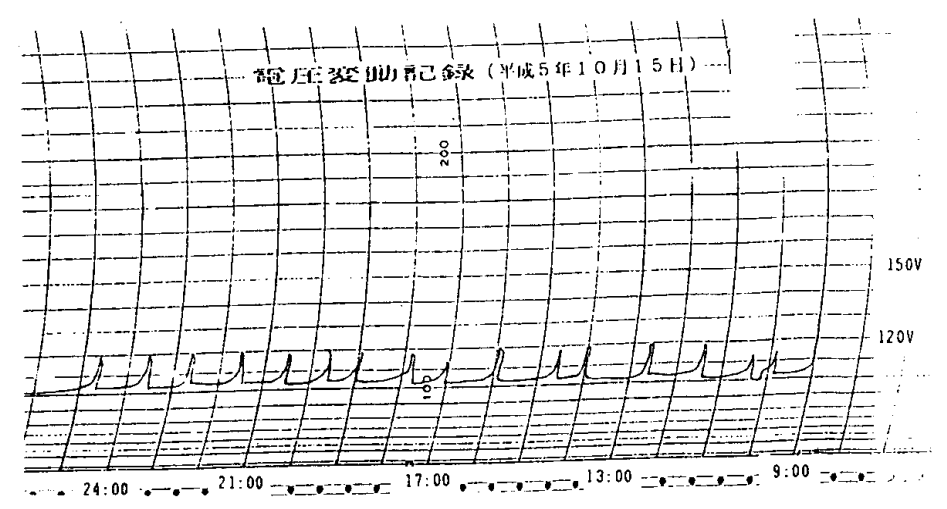

$$
\text { 図-1 }
$$

また、電気室内の各トランス別の電生測定お よび各分電盤接地幹線（院内 25 所）の漏れ 電流値の測定を行い、正常時および異常時の 漏れ電流值の比較調查を実施した。

10月29日测定を実施した結果、4 階動物舎( $4 \mathrm{LE}-3$ 分電盤) の電流值（840mA正常值の約 20 倍）の異常が確認されたため、動物舎内の回 路別にブレカーを遮断し、漏れ電流值および 電圧の変動を調查した。

動物実験室内の実験台コンセント回路（電 気ポット使用中）を遮断した際に正常值とな ったため電気ポットおよびコンセントを点検 した結果、コンセントのアース線とニュート ラル線が逆配線されていた。

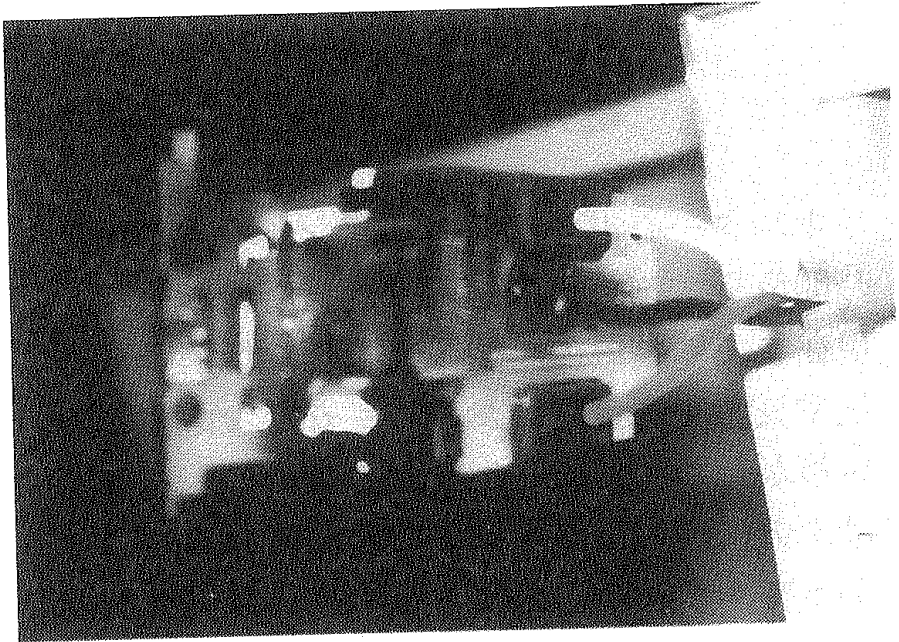

写真 -2

正常の配線に民し漏れ電流值を測定した結 果、正常值になったため、この誤配線された コンセントで電気ポットを使用していたため 断続的な異常電圧が起きたと思われる。

\section{3. 結語}

今回起きた異常電圧は電気機器の電源コ一 ドの損傷およびコンセントの誤配線が原因の 対地間異常電圧であった。異常電圧等でその 原因究明おいては、電気設備全般の調査が必 要で特に末端の分電盤においては負荷の状況 から電源を遮断することが難しいため調查が 難抗した。幸い院内の電気設備および医療機 器等に大きなトラブルがなかったが、末端で 使用している医療機器等に影響し過大な漏れ 電流による電撃の危険性があること、また病 棟の一室が停電するといった事態が起こった 様に今後の電気設備に対する注意が必要であ る。

異常電圧は何れも M E センター部で保守管 理している医療機器の接地漏れ電流測定時に 発見した。しかし、当施設の電気設備に於い ては電圧の異常に対する監視装置が備えられ ていないため、日常の保守管理による監視が 重要になる。今後の対策として電圧および電 流等を常時監視できる測定装置等の装備によ り、電気設備に対する安全性の確保が必要と 思われる。 